\title{
Seasonal Variation of 'Candidatus Liberibacter asiaticus' Titers in New Shoots of Citrus in Distinct Environments
}

\author{
Silvio A. Lopes, Fernanda Q. B. F. Luiz, and Hermes T. Oliveira, Fundecitrus, Araraquara, SP, Brazil; and Juan C. Cifuentes-Arenas and
} Laudecir L. Raiol-Junior, Universidade Estadual Paulista, Jaboticabal, SP, Brazil

\begin{abstract}
The major citrus area of Brazil occupies near 450,000 ha between the Triângulo Mineiro (TM) region of Minas Gerais State and the south of São Paulo State (SPS). Significant climatic variation occurs between regions which could affect huanglongbing (HLB) progress, which is lower in TM. To investigate this possibility, young sweet orange shoots were sampled periodically over 2 years to determine 'Candidatus Liberibacter asiaticus' titers in naturally infected trees in orchards in Analândia, central SPS, and Frutal and Comendador Gomes, within TM. Data-loggers recorded local temperature and relative humidity hourly. In the laboratory, five ' $\mathrm{Ca}$. L. asiaticus'-free Diaphorina citri adults were placed on each sampled shoot for $48 \mathrm{~h}$ to feed and acquire the pathogen. Shoots and insects were individually analyzed by quantitative polymerase chain

reaction to determine ' $\mathrm{Ca}$. L. asiaticus' titers. The incidence of ' $\mathrm{Ca}$. L asiaticus'-positive shoots, ' $\mathrm{Ca}$. L. asiaticus' titers, and acquisition rates were lower for shoots from Comendador Gomes than those from Frutal or Analândia. Stronger association was observed between ' $\mathrm{Ca}$. L. asiaticus' titers and the number of hours below $15^{\circ} \mathrm{C}\left(\mathrm{h}<15^{\circ} \mathrm{C}\right)$ or above $30^{\circ} \mathrm{C}\left(\mathrm{h}>30^{\circ} \mathrm{C}\right)$, and cumulative rainfall registered during the 15 days prior to sampling of shoots on each occasion. ' $\mathrm{Ca}$. L. asiaticus' titers associated positively with $\mathrm{h}\left\langle 15^{\circ} \mathrm{C}\right.$ and rainfall and negatively with $\mathrm{h}>$ $30^{\circ} \mathrm{C}$. The slower spread and lower incidence of HLB in TM may be related to lower incidences of ' $\mathrm{Ca}$. L. asiaticus'-positive young shoots and lower titers of ' $\mathrm{Ca}$. L. asiaticus' in the same shoots as a consequence of the warmer and drier conditions.
\end{abstract}

Huanglongbing (HLB) is the most destructive disease of citrus (Bové 2006). In Brazil, it is associated with 'Candidatus Liberibacter asiaticus', which has been detected in over $99 \%$ of the Liberibacterinfected trees in São Paulo State (SPS), and ' $\mathrm{Ca}$. L. americanus' (Coletta-Filho et al. 2004; Lopes et al. 2013, Teixeira et al. 2005). Both Liberibacters are transmitted by the Asiatic citrus psyllid (ACP) Diaphorina citri (Capoor et al. 1967; Yamamoto et al. 2006). HLB was first reported in 2004 in the central SPS and later detected in all of SPS plus the major citrus areas of Minas Gerais and Paraná States (Fundecitrus 2015a; Nunes et al. 2010). D. citri was first reported in 1942 in sweet orange trees in Rio de Janeiro State (da Costa-Lima 1942) and today is present in all citrus-growing regions in Brazil.

The major citrus area of Brazil encompass most of SPS and, in the far north, the Triângulo Mineiro region of Minas Gerais State (TM). Spread of ' $C a$. L. asiaticus' within the area has not been uniform despite the distribution and size of citrus orchards serving as host bridges favorable for uniform spread of ' $\mathrm{Ca}$. L. asiaticus' by the psyllid. In TM, the pathogen was detected later and has progressed at a slower rate than in other regions (Belasque Júnior et al. 2009; Fundecitrus 2015a). The reasons for the lower rate of disease progress are not clear but could involve local inoculum pressure or the influence of the environment on the components of the HLB-ACP pathosystem. In TM, summers are hotter and rainfall is not as evenly distributed as in most southern regions, especially during winter (Rolim et al. 2007). These factors could affect ACP and ' $C a$. L. asiaticus' and, consequently, influence the spread of HLB.

The impact of the environment on ACP is well known. In controlled environments, the optimum range of temperatures for $\mathrm{ACP}$ reproduction and survival was 25 to $28^{\circ} \mathrm{C}$ (Liu and Tsai 2000). However, studies based on controlled-environment conditions do not accurately reflect effects of temperature on ACP, which can survive daily maximum temperatures of $45^{\circ} \mathrm{C}$ and above at low relative

Corresponding author: S. A. Lopes; E-mail: silvio.lopes@ fundecitrus.com.br Accepted for publication 15 November 2016.

() 2017 The American Phytopathological Society humidity (Aubert 1990; Beattie and Barkley 2009; Khan et al. 2014; Razi et al. 2014). In the northern SPS regions, the climate seems to favor ACP. Based on thermal and humidity requirements for the insect in Brazil (namely, 18 to $30^{\circ} \mathrm{C}$ and 70 to $85 \%$ relative humidity) (Nava et al. 2007), Gómez-Torres (2009) estimated 10 to 13 generations of the psyllid per year in the northern SPS compared with 3 to 10 in the other regions.

Evidence for the impact of temperature on ' $\mathrm{Ca}$. L. asiaticus' also has been documented. In Florida in the United States and in the northern Paraná State in Brazil, mature leaves of naturally infected trees contained lower titers of ' $\mathrm{Ca}$. L. asiaticus' during the hotter months (Gottwald et al. 2012; Sauer et al. 2015). Similarly, in artificially inoculated potted plants exposed to daily temperatures of 24 to $38^{\circ} \mathrm{C}$ in growth chambers, ' $\mathrm{Ca}$. L. asiaticus' titers were, on average, about four $\log$ units lower than in plants exposed to 24 to 32 or 24 to $35^{\circ} \mathrm{C}$. Decrease in ' $\mathrm{Ca}$. L. asiaticus' titer was detected in fully expanded mature leaves (Gasparoto et al. 2012; Lopes et al. 2009b) and in soft immature young shoots (Lopes et al. 2013). In young shoots, the lower titers also were consistently associated with lower acquisition rates of the pathogen by adult psyllids. In another study also involving adult psyllids, ' $C a$. L. asiaticus' titers decreased in ' $\mathrm{Ca}$. L. asiaticus'-positive insects exposed to continuous ambient temperatures of 38 as well as $14^{\circ} \mathrm{C}$ but not in those exposed to 20 , 26 , or $32^{\circ} \mathrm{C}$ (Lopes and Luiz 2013).

In an attempt to better understand the potential impact of climate variables on ' $C a$. L. asiaticus' and, consequently, on the spread of HLB, ' $\mathrm{Ca}$. L. asiaticus' titers were assessed in new immature shoots of citrus trees naturally infected by the pathogen, growing in orchards located within three regions of contrasting climate within the major citrus area of Brazil. Preliminary results of this work were already presented (Lopes et al. 2015).

\section{Materials and Methods}

Sampled trees. The study was conducted from September 2012 to September 2014 in three citrus orchards: one in Analândia municipality $(22.129243,47.662772,668 \mathrm{~m}$ above sea level [ASL]) in central SPS and two in southern TM, one in Frutal (20.026483, 48.936448, $534 \mathrm{~m} \mathrm{ASL}$ ) and the other in Comendador Gomes (19.697289, 49.083622, 572 m ASL) municipality. The Frutal and Comendador Gomes farms are 250 to $300 \mathrm{~km}$ north of the one in Analândia. 
Data from the previous 5 years (2007 to 2011) for the farm sites indicated that, during the warmer period (October to April), the average daily maximum and minimum temperatures and total precipitation were 31.3 and $17.1^{\circ} \mathrm{C}$ and $1,574 \mathrm{~mm}$ in Analândia, 33.7 and $20.4^{\circ} \mathrm{C}$ and $1,592 \mathrm{~mm}$ in Frutal, and 31.3 and $20.1^{\circ} \mathrm{C}$ and $1,726 \mathrm{~mm}$ in Comendador Gomes, respectively. During the cooler period (May to August) of the same years, the average maximum and minimum temperatures and precipitation were 27.1 and $11.4^{\circ} \mathrm{C}$ and $156 \mathrm{~mm}$ in Analândia, 31.6 and $14.8^{\circ} \mathrm{C}$ and $77 \mathrm{~mm}$ in Frutal, and 29.6 and $16.3^{\circ} \mathrm{C}$ and $72 \mathrm{~mm}$ in Comendador Gomes, respectively. In central SPS, HLB was found in 2004, and increased from $1.20 \%$ symptomatic trees in 2008 to $26.97 \%$ in 2016 . In TM, the disease was found in 2009 and increased from $0.04 \%$ in 2009 to $0.40 \%$ in 2016 (www.fundecitrus.com.br). The effects of the environment on ' $\mathrm{Ca}$. L. asiaticus' titer in citrus at each location were assessed by excising immature new shoots from naturally infected mature trees and, as described below, allowing adult $D$. citri to feed on them; then, subsequently, determining ' $\mathrm{Ca}$. L. asiaticus' titers in the flushes and psyllids.

Six to seven 11-year-old trees of 'Valencia' and 'Natal' sweet orange grafted onto 'Swingle' citrumelo rootstock were selected for the study on each farm. All trees were expressing characteristic HLB leaf symptoms caused by ' $\mathrm{Ca}$. L. asiaticus', and presence of the pathogen was confirmed by quantitative real-time polymerase chain reaction (qPCR) (Li et al. 2009). For the study, secondary branches of each tree were cut approximately $1.5 \mathrm{~m}$ above ground level, and an iron frame ( 3 by 3 by $3 \mathrm{~m}$ ) covered with a transparent screen $(0.87-$ by $0.30-\mathrm{mm}$ mesh) to exclude $D$. citri was used to cage each tree in September 2012. The plants were pruned again in January and August 2013 by cutting the top $30 \mathrm{~cm}$ of the secondary branches.

Just before the first pruning, all branches with symptoms of HLB were labeled and symptomatic leaves were sampled to confirm the presence of ' $\mathrm{Ca}$. L. asiaticus' by qPCR. With the exception of one tree on the Comendador Gomes farm, all trees tested positive for ' $C a$. L. asiaticus'. The ' $C a$. L. asiaticus'-negative tree was removed from the experiment, as was another on same farm that tested positive for a phytoplasma closely related to pigeon pea witches-broom phytoplasma (Teixeira et al. 2008). In January 2013, mature symptomatic leaves sampled from the ' $\mathrm{Ca}$. L. asiaticus'-positive trees of Analândia, Frutal, and Comendador Gomes contained an average of $\log 5.08 \pm 0.2,4.50 \pm 0.2$, and $3.5 \pm 1.1$ 'Ca. L. asiaticus' cells per gram of tissue, respectively. Data-loggers (Log Box RHT LCD, Porto Alegre, RS) programmed to record relative humidity and air temperatures hourly were placed $1.5 \mathrm{~m}$ above ground level, in one corner within one cage at each location. An identical data-logger was located near the administrative office of each farm, close to a rain gauge that recorded daily rainfall. The administrative office of each farm was located 3.4, 1.8, and $1.2 \mathrm{~km}$ distant from the caged tree in the Analândia, Frutal, and Comendador Gomes farms, respectively.

At 2 to 3 weeks before the date planned for sampling immature flushes, the top $50 \mathrm{~cm}$ of the selected symptomatic branches were defoliated to induce new growth. The defoliated branches were observed weekly and, when new shoots were 5 to $10 \mathrm{~cm}$ long, with recently formed soft new leaves, four shoots were collected randomly from each tree and immediately placed in separate 50-ml Falcon tubes containing $20 \mathrm{ml}$ of distilled water. Before sampling, the new shoots were sprayed thoroughly with detergent and tap water, which we observed previously to efficiently remove any chemical residues that could interfere with feeding by $D$. citri adults. The tubes were maintained inside a foam box and transported to the Fundecitrus laboratories at Araraquara, SPS, where each new shoot was transferred individually to fresh Falcon tubes containing $15 \mathrm{ml}$ of milliQ distilled water (procedures modified from Ammar et al. [2013]). This procedure was chosen and carried out in the lab to minimize any potential influence that the distinct environments and climate of the distinct locations and sampling dates could have on the feeding behavior of the insects. The stem end of each new shoot was removed with a razor blade and the basal portion of the top $5 \mathrm{~cm}$ that remained was threaded through a small hole in the center of a 50-mm-diameter piece of filter paper before the shoot was placed in the tube. Five
2- to 3-week-old $D$. citri adults raised on healthy orange jasmine (Murraya exotica L.) plants were transferred to each new shoot, in their separate Falcon tubes, with each tube covered with a fine mesh cloth to prevent escape of the insects. Contact of the psyllids with water was prevented by the filter paper through which the stem end of each shoot had been inserted. The insects were maintained on the new shoots in the Falcon tubes at $26^{\circ} \mathrm{C}$ for a $48-\mathrm{h}$ ' $\mathrm{Ca}$. L. asiaticus' acquisition access period (AAP). The new shoots and the insects were then processed individually for DNA extraction and qPCR analysis, with the quantification cycle $(\mathrm{Cq})$ values converted into log of the amount of ' $\mathrm{Ca}$. L. asiaticus' amplicons per gram of new shoot tissue or per insect.

DNA extractions and quantifications from plant tissues and insects, qPCR procedures, and conversion of $\mathrm{Cq}$ values in ' $\mathrm{Ca}$. L. asiaticus' titers were conducted as described previously (Lopes et al. 2013), using the same quantification curve prepared with the product of the gene $16 \mathrm{~S}$ ribosomal RNA (rRNA) of ' $\mathrm{Ca}$. L. asiaticus', with the exception that all the insects were analyzed individually, and the internal control primers for the cytochrome oxidase $(\mathrm{Cox})(\mathrm{Li}$ et al. 2009) and wingless (Wg) (Manjunath et al. 2008; Thao et al. 2000) gene regions of citrus and $D$. citri were used in all qPCR. Samples that resulted in "undetermined" or in Cq values above 34.0 were taken as negative for ' $\mathrm{Ca}$. L. asiaticus' in both citrus and insect samples. The few samples with $\mathrm{Cq}$ values above 34.0 for Cox or $\mathrm{Wg}$ genes usually resulted in $\mathrm{Cq}$ values higher than 34.0 for ' $\mathrm{Ca}$. $\mathrm{L}$. asiaticus' and were not included in the data analysis.

Data analysis. The percentage of ' $\mathrm{Ca}$. L. asiaticus'-positive new shoots or insects (arcsin transformed) and the average estimates of ' $C a$. L. asiaticus' titers in new shoots or insects were subjected to analysis of variance, with the means compared using the Tukey's test $(P<0.05)$. Each tree was considered a replication. The assessed parameters were subjected to simple linear regression analysis to estimate the titer of ' $\mathrm{Ca}$. L. asiaticus' in new shoots required for effective bacterium acquisition by 10 or $20 \%$ of the adult psyllids. Multiple linear regression analysis was used in attempts to identify the relative importance of climatic factors on ' $\mathrm{Ca}$. L. asiaticus' multiplication in new shoots. The climatic factors consisted of the number of hours at different ranges of temperature and relative humidity, plus the amount of rain in millimeters that accumulated during the last 7,15 , or 30 days immediately prior to each sampling date. These time intervals were selected based on previous studies (Lopes et al. 2013) and on the dynamics of new shoot development in citrus (Cifuentes-Arenas et al. 2016). The Statistica software (StatsSoft, Tulsa, OK) was used for all analyses.

\section{Results}

Seasonal variation in ' $\mathrm{Ca}$. L. asiaticus' titer and bacterium acquisition. In this study, we assessed ' $\mathrm{Ca}$. L. asiaticus' titer in new shoots of ' $C a$. L. asiaticus'-infected trees growing at one location in SPS and two locations in TM. We also assessed ' $\mathrm{Ca}$. L. asiaticus' titers in adult $D$. citri that fed on the shoots under laboratory conditions.

At the beginning of the study, the estimated average percentage of the canopy showing symptoms on mature leaves was $14.2 \pm 2.15$ at Analândia, $11.2 \pm 3.37$ at Frutal, and $9.0 \pm 5.02$ at Comendador Gomes. The symptomatic branches selected for samplings developed new shoots on most experimental trees at all six sampling dates; namely, 10 September 2012, 21 March 2013, 12 July 2013, 6 November 2013, 12 February 2014, and 9 September 2014 for Analândia; 13 September 2012, 6 March 2013, 27 June 2013, 7 November 2013, 10 February 2014, and 6 September 2014 for Frutal; and 19 October 2012, 5 March 2013, 27 June 2013, 7 November 2013, 10 February 2014, and 27 August 2014 for Comendador Gomes. During summer 2014, the time between defoliation and sampling date and the final size of the new shoots were evaluated. Overall, the shoots grew faster and reached greater lengths at Comendador Gomes $(0.35 \mathrm{~cm} /$ day, $10.09 \pm 0.34 \mathrm{~cm}$ long $)$ and Frutal $(0.36 \mathrm{~cm} /$ day, $10.22 \pm 0.33$ long $)$ than at Analândia $(0.29 \mathrm{~cm} /$ day, $8.73 \pm 0.21$ long $)$.

In the laboratory, adults of ' $C a$. L. asiaticus'-free $D$. citri were allowed to feed on new shoots for $48 \mathrm{~h}$ for them to acquire the pathogen. The majority of the insects survived the AAP. The new shoots 
and the insects were then processed individually for ' $\mathrm{Ca}$. L. asiaticus' detection and quantification using primers specific for ' $\mathrm{Ca}$. L. asiaticus' and for citrus and D. citri internal controls. Analysis of the $\mathrm{Cq}$ values for the internal controls indicated that $99.16 \%$ of the ' $\mathrm{Ca}$. L. asiaticus'-positive and -negative samples of citrus, and $99.12 \%$ of the ' $C a$. L. asiaticus'-positive and -negative samples of $D$. citri, contained adequate amounts of citrus or D. citri DNA for qPCR amplifications. The $\mathrm{Cq}$ values for Cox averaged $18.00 \pm 0.10$ in ' $\mathrm{Ca}$. $\mathrm{L}$. asiaticus'-positive and $17.84 \pm 0.84$ in ' $\mathrm{Ca}$. L. asiaticus'-negative citrus samples. The $\mathrm{Cq}$ values for $\mathrm{Wg}$ averaged $23.67 \pm 0.14$ in ' $\mathrm{Ca}$. $\mathrm{L}$. asiaticus'-positive and $24.93 \pm 0.08$ in ' $\mathrm{Ca}$. L. asiaticus'-negative D. citri samples. The Cq values for the $16 \mathrm{~S}$ rRNA of ' $\mathrm{Ca}$. L. asiaticus' were then converted into $\log _{10}$ per gram of new shoot or per individual insect.

The proportion of ' $\mathrm{Ca}$. L. asiaticus'-positive new shoots or insects was used to estimate the percentage of samples carrying the bacterium. The averages remained higher in the new shoots from trees from the orchard located in Analândia than in those in Frutal or Comendador Gomes for all four evaluated variables (Table 1). ' $\mathrm{Ca}$. L. asiaticus' titers in $\mathrm{D}$. citri were marginally different among locations $(P=0.0575)$. On average, $53.43 \%$ of new shoots from Analândia contained $2.27 \log$ ' $C a$. L. asiaticus' cells per gram of tissue. At Frutal and Comendador Gomes, ' $\mathrm{Ca}$. L. asiaticus' was found in 46.11 and $19.41 \%$ of new shoots, respectively, and these shoots contained 1.83 and $0.70 \mathrm{log}$ cells/g of tissue. The pathogen was detected in $6.38,4.56$, and $1.65 \%$ of adult $D$. citri that fed for $48 \mathrm{~h}$ on all new shoots each from Analândia, Frutal, or Comendador Gomes orchards, respectively. Concentrations of the pathogen in the insects averaged $0.44,0.29$, and $0.10 \mathrm{log}$ cells/g of tissue, respectively. The bacterium was not detected by qPCR in the new shoots sampled in February 2014 (Fig. 1). At Comendador Gomes, the pathogen was also not detected on 19 October 2012 and 27 August 2014 (Fig. 1 A and $\mathrm{B}$ ). None of the insects that fed on those new shoots were positive by qPCR (Fig. 1C and D).

Linear regression was used to study the relationship between the percentage of ' $\mathrm{Ca}$. L. asiaticus'-positive new shoots, the percentage of ' $\mathrm{Ca}$. L. asiaticus'-positive insects, and ' $\mathrm{Ca}$. L. asiaticus' titer in insects (dependent variables) and ' $C a$. L. asiaticus' titer in new shoots (Table 2$)$. Significant relationships $(P<0.0001)$ resulted for all pairwise comparison, and indicated that an increase in ' $\mathrm{Ca}$. L. asiaticus' titer in new shoots would lead to an increase in the parameters for all three dependent variables tested. The resulting models accounted for 59.7 to $98.8 \%$ of the variability of the data. The titer needed for ' $\mathrm{Ca}$. L. asiaticus' acquisition by 10 and $20 \%$ of the adult psyllids (effective titer 10 and 20) was, on average, 1.8 and 1.7 times higher, respectively, for the new shoots from Comendador Gomes than for those from Analândia and Frutal.

Climatic factors and ' $\mathrm{Ca}$. L. asiaticus' titer in new shoots. Data loggers were installed inside and outside the cages to record temperature and relative humidity every hour. In general, inside the cages, relative humidity levels were higher than those from outside but at comparable levels ( $<6 \%$ difference) most of the time. The temperature data from inside the cage also were generally similar $\left( \pm 1^{\circ} \mathrm{C}\right)$ to those from outside most of the time but reached lower values than outside during the early mornings (09:00 to 11:00) and higher values during the late evenings (14:00 to 18:00), increasing progressively and reaching a maximum $3.8^{\circ} \mathrm{C}$ difference at about $16: 00$ during the hottest days.

During the entire period of the study, precipitation generally followed the tendency observed in the last decade for the two selected periods: one wet, going from early spring to middle autumn (September to April), and one dry, going from middle autumn to early spring (May to August) (Table 3). During the wet seasons of 2012-13, rainfall totals were higher in the Analândia $(1,509 \mathrm{~mm})$ than in the other two farms (1,320 and 1,324 mm). During the wet season of 2013-14, Analândia and Comendador Gomes accumulated similar amounts $(1,327$ and $1,377 \mathrm{~mm})$ of rain, which were higher than those in Frutal $(1,136 \mathrm{~mm})$. During the dry seasons, Analândia accumulated higher amounts of rain $(265$ and $108 \mathrm{~mm})$ than Frutal $(182$ and $60 \mathrm{~mm})$ or Comendador Gomes (166 and $78 \mathrm{~mm}$ ) in both seasons (2012-13 and 2013-14). Also, in those periods, the number of rainy days were higher in Analândia (18 and 8) than in Frutal (10 and 6) or Comendador Gomes (9 and 6).

To identify the weather variables that could have influenced ' $\mathrm{Ca}$. L. asiaticus' titers in new shoots, titer and weather data were subjected to multiple linear regression analysis. The data consisted of hours at temperatures within $5^{\circ} \mathrm{C}$ intervals (e.g., 1 to $5^{\circ} \mathrm{C}, 6$ to $10^{\circ} \mathrm{C}$, and so on), relative humidity over 50 or $80 \%$, and cumulative rainfall (in millimeters) recorded over 7,15 , and 30 days prior to each sampling date.

The best regression models accounted for 45 to $76 \%$ of the observed variation in ' $C a$. L. asiaticus' titer in new shoots, with the number of hours above $30^{\circ} \mathrm{C}\left(\mathrm{h}>30^{\circ} \mathrm{C}\right)$ and below $15^{\circ} \mathrm{C}(\mathrm{h}<$ $15^{\circ} \mathrm{C}$ ), and the cumulative rainfall as the best predictor variables (Table 4). Accordingly, ' $\mathrm{Ca}$. L. asiaticus' titer in new shoots is expected to decrease as $\mathrm{h}>30^{\circ} \mathrm{C}$ increases, and to increase as $\mathrm{h}<$ $15^{\circ} \mathrm{C}$ plus the cumulative rainfall increase (Table 4 ). The highest prediction power (higher $R^{2}$ and lower model $P$ values) was attained with the weather conditions registered during the last 15 days prior to sampling dates (Table 4). These conditions are shown in Table 5 for all three locations. The coolest and hottest periods were September to October 2012 and February 2014, respectively, when the highest $\mathrm{h}<15^{\circ} \mathrm{C}$ and $\mathrm{h}>30^{\circ} \mathrm{C}$ values were observed. The wettest periods were November 2013 for Analândia and Comendador Gomes (183 and $108 \mathrm{~mm}$ ), and March 2013 for Frutal $(130 \mathrm{~mm})$. September and October 2012 and August and September 2014 were the driest periods in all three locations. Overall, Analândia was coolest and wettest, and Comendador Gomes warmest and driest.

Additional information on the temperature prevalence inside the cages is shown in Figure 2. In Analândia, the temperature varied between 6 and $47^{\circ} \mathrm{C}$, ranging from 10 to $27^{\circ} \mathrm{C}$ most of the time $(66.1 \%)$, and reaching the longest period $(23.2 \mathrm{~h})$ at $19^{\circ} \mathrm{C}$. In Frutal, the temperature varied between 11 and $46^{\circ} \mathrm{C}$, ranging from 14 to $28^{\circ} \mathrm{C}$ most

Table 1. Average percentages of 'Candidatus Liberibacter asiaticus'-positive and bacterium titers in individual new shoots, and of 'Ca. L. asiaticus'-positive and bacterium titers in individual adult Diaphorina citri after a 48-h acquisition access period, on six occasions at each of three locations of the main citrus-growing area of Brazil from September 2012 to September $2014^{\mathrm{w}}$

\begin{tabular}{|c|c|c|c|c|c|}
\hline \multirow[b]{2}{*}{ Location } & \multirow[b]{2}{*}{ Total $^{\mathbf{z}}$} & \multicolumn{2}{|c|}{ New shoots ${ }^{x}$} & \multicolumn{2}{|c|}{ D. citri $^{\mathrm{y}}$} \\
\hline & & Positive (\%) & Titer & Positive (\%) & Titer \\
\hline Analândia & 34 & $53.43 \pm 6.11 \mathrm{a}$ & $2.27 \pm 0.29 \mathrm{a}$ & $6.38 \pm 1.07 \mathrm{a}$ & $0.44 \pm 0.09 \mathrm{a}$ \\
\hline Frutal & 33 & $46.11 \pm 7.43 \mathrm{a}$ & $1.83 \pm 0.29 \mathrm{a}$ & $4.56 \pm 1.09 \mathrm{ab}$ & $0.29 \pm 0.09 \mathrm{ab}$ \\
\hline Comendador Gomes & 23 & $19.41 \pm 6.20 \mathrm{~b}$ & $0.70 \pm 0.35 b$ & $1.65 \pm 1.30 \mathrm{~b}$ & $0.10 \pm 0.10 b$ \\
\hline$F_{2,87}$ & & 6.59 & 6.22 & 3.94 & 2.95 \\
\hline$P$ & & 0.0022 & 0.0030 & 0.0229 & 0.0575 \\
\hline
\end{tabular}

${ }^{\mathrm{w}}$ Quantification cycle values above 34.0 were considered negative for new shoot or $D$. citri samples. Titer in log ${ }_{10}$ of amplicon copies per gram of new shoot tissue or individual insect, estimated based on a standard curve as described (Lopes et al. 2013). Positive = percentage of 'Ca. L. asiaticus'-positive samples and Titer $=$ 'Ca. L. asiaticus' titer.

${ }^{x}$ Each sample consisted of four newly developed shoots.

y Each sample consisted of 20 adult insects.

$\mathrm{z}$ Number of samples collected from huanglongbing-affected trees. 
of the time $(67.0 \%)$ and reaching the longest period $(32.0 \mathrm{~h})$ at $21^{\circ} \mathrm{C}$. In Comendador Gomes, the temperature varied between 16 and $46^{\circ} \mathrm{C}$, ranging from 18 and $28^{\circ} \mathrm{C}$ most of the time $(66.0 \%)$ and reaching the longest period $(35.3 \mathrm{~h})$ at $22^{\circ} \mathrm{C}$. Temperatures over $40^{\circ} \mathrm{C}$ were recorded prior to most sampling dates (except in the winter, with the highest at $37^{\circ} \mathrm{C}$ ) but were generally of short duration (average of 0.16 $\mathrm{h}$ /day), not exceeding $44^{\circ} \mathrm{C}$. February 2014 was an exception, with the average period above $40^{\circ} \mathrm{C}$ reaching $0.67 \mathrm{~h} /$ day, with the highest daily temperature reaching $47^{\circ} \mathrm{C}$ (Fig. 2).

\section{Discussion}

The influence of the climate on "greening" occurrence and dissemination is well known in countries such as South Africa, where both the pathogen (' $\mathrm{Ca}$. L. africanus') and the insect vector (Trioza erytreae Del Guercio; Triozidae) are heat sensitive (Bové et al. 1974; Schwarz and Green 1972), but not in countries such as Brazil, where the prevalent pathogen (' $\mathrm{Ca}$. L. asiaticus') and the insect vector ( $D$. citri) are both heat tolerant (Bové et al. 1974; Lopes et al. 2009a; McFarland and Hoy 2001). Influences of climate on the incidence and severity of HLB in Brazil were considered possible a few years after the first report of the disease in SPS, when initial observations indicated that the disease appeared later and was less severe in regions with hotter summers and drier winters. These relationships were confirmed in later surveys (Belasque Júnior et al. 2009; Lopes et al. 2009a).

To generate additional information on this phenomenon, a series of experiments was conducted in growth chambers. In plants exposed to $38^{\circ} \mathrm{C}$ for $6 \mathrm{~h} /$ day for at least 4 days, ' $\mathrm{Ca}$. L. asiaticus' titers decreased in mature leaves (Lopes et al. 2009a) and in new shoots (Lopes et al. 2013). In the present study, high temperatures (over $30^{\circ} \mathrm{C}$ ) also affected ' $\mathrm{Ca}$. L. asiaticus' but the effect was weaker than that observed in growth chambers. The reason could be the lower amount of exposure hours at or above $38^{\circ} \mathrm{C}$ per day in the field (average of $0.27 \mathrm{~h}$ ) compared with the growth chamber (6h). In addition,
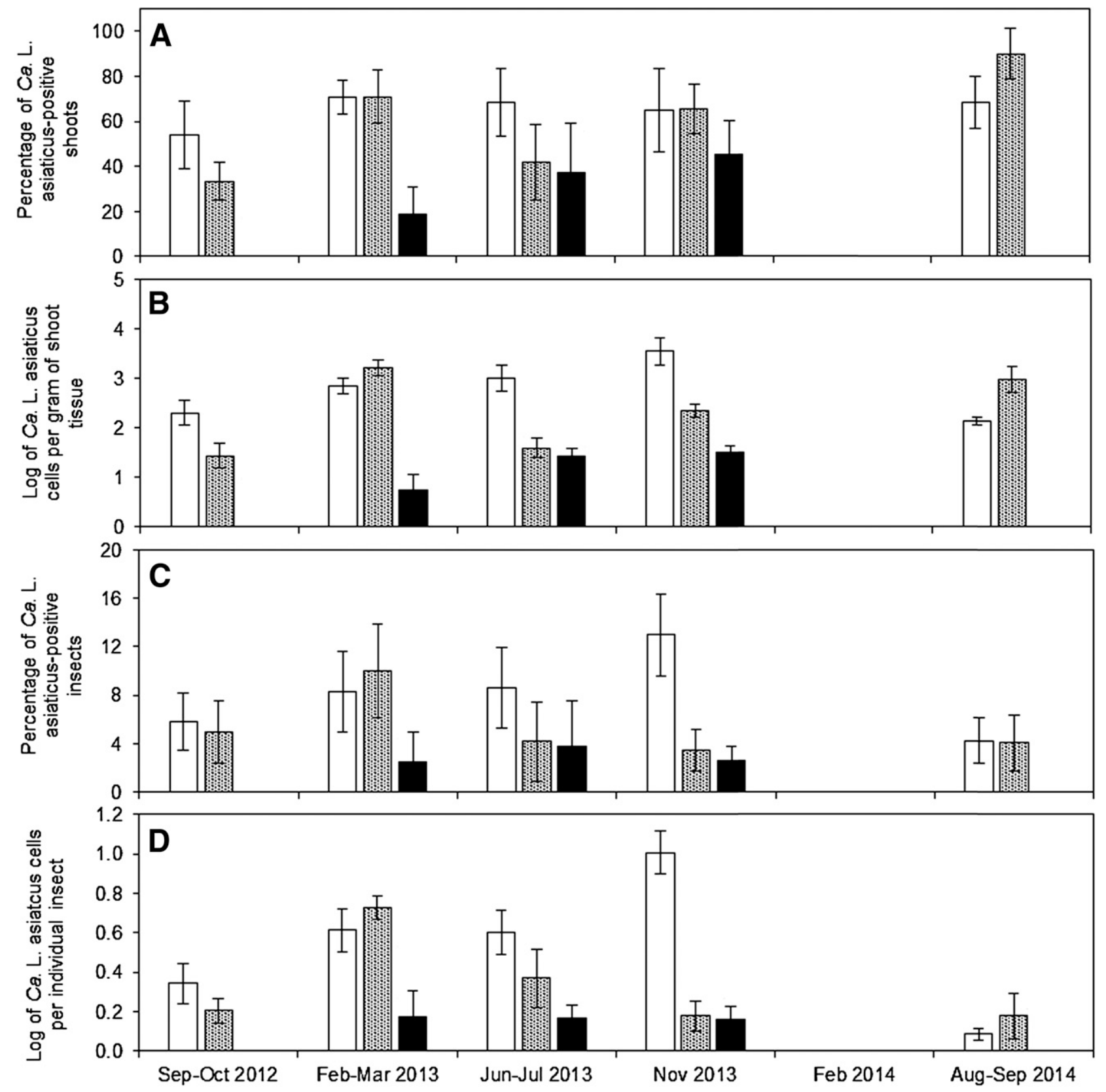

Fig. 1. Percentage of A, 'Candidatus Liberibacter asiaticus'-positive and B, 'Ca. L. asiaticus' titers in new shoots from adult huanglongbing-affected trees from Analândia (white bars), Frutal (gray bars), or Comendador Gomes (black bars), and percentage of C, 'Ca. L. asiaticus'-positive and D, 'Ca. L. asiaticus' titers in adult Diaphorina citri after a 48-h acquisition access period on the new shoots, assessed from September 2012 to September 2014. 
in the field (Analândia and Frutal), the trees were exposed concomitantly to low temperatures (below $15^{\circ} \mathrm{C}$ ) and rainfall, which seemed to favor ' $\mathrm{Ca}$. L. asiaticus' at a greater extent than high temperatures (Table 4). Prolonged dry periods associated with high temperatures usually prevail from mid-autumn through winter in northern SPS and TM regions. In these situations, adult trees suffer from water deficits, which may influence not only ' $C a$. L. asiaticus' but also ACP, in this instance decreasing the availability of appropriate feeding and reproduction sites for the insects. A decrease in ' $\mathrm{Ca}$. L. asiaticus' and
ACP populations would contribute to reduce ' $\mathrm{Ca}$. L. asiaticus' dissemination and disease spread, corroborating field surveys (Fundecitrus 2015b).

Further evidence for the favorability of low temperature (and probably soil moisture) to ' $\mathrm{Ca}$. L. asiaticus' is found in the Frutal farm. Although within a region where HLB has progressed at a lower rate, the Frutal farm is located near a large expanse of water (approximately 2,000 m wide) formed by the Rio Grande River, which separates the States of São Paulo and Minas Gerais. At its closest

Table 2. Simple linear regression models for predicting the frequency of 'Candidatus Liberibacter asiaticus'-positive adult Diaphorina citri and bacterium titer in the insects at each of three locations of the main citrus-growing area of Brazil, with the bacterium titer in new shoots as the predictor variable

\begin{tabular}{|c|c|c|c|c|c|c|}
\hline \multirow[b]{2}{*}{ Location } & \multicolumn{2}{|c|}{ Parameter } & \multirow[b]{2}{*}{ Statisticsw $^{\text {w }}$} & \multirow[b]{2}{*}{ Adjusted $R^{2}$} & \multicolumn{2}{|c|}{ Effective titer ${ }^{v}$} \\
\hline & Intercept & Slope & & & 10 & 20 \\
\hline \multicolumn{7}{|l|}{ Positive shoots $(\%)^{\mathrm{x}}$} \\
\hline Analândia & 0.782 & 4.559 & $F_{1,32}=626.41$ & 94.99 & $\ldots$ & $\ldots$ \\
\hline Frutal & 0.360 & 5.019 & $F_{1,31}=580.95$ & 94.77 & $\ldots$ & $\ldots$ \\
\hline Comendador Gomes & 0.098 & 5.557 & $F_{1,21}=1108.83$ & 98.05 & $\ldots$ & $\ldots$ \\
\hline All & 0.4416 & 4.836 & $F_{1,88}=2162.88$ & 96.05 & $\ldots$ & $\ldots$ \\
\hline \multicolumn{7}{|l|}{ Positive insects $(\%)^{\mathrm{y}}$} \\
\hline Analândia & -0.281 & 3.395 & $F_{1,32}=59.94$ & 64.11 & 3.03 & 5.97 \\
\hline Frutal & -0.470 & 3.154 & $F_{1,31}=75.82$ & 59.67 & 3.32 & 6.49 \\
\hline Comendador Gomes & -0.344 & 1.879 & $F_{1,21}=94.06$ & 80.88 & 5.50 & 10.83 \\
\hline All & -2.129 & 3.354 & $F_{1,88}=184.81$ & 67.38 & 3.62 & 6.60 \\
\hline \multicolumn{7}{|l|}{ Titers in insects ${ }^{\mathrm{z}}$} \\
\hline Analândia & 0.105 & 0.044 & $F_{1,32}=68.51$ & 67.17 & $\ldots$ & $\ldots$ \\
\hline Frutal & -0.010 & 0.040 & $F_{1,31}=93.17$ & 74.23 & $\ldots$ & $\ldots$ \\
\hline Comendador Gomes & 0.033 & 0.039 & $F_{1,21}=59.28$ & 72.60 & $\cdots$ & $\ldots$ \\
\hline All & -0.024 & 0.426 & $F_{1,88}=234.57$ & 72.41 & $\ldots$ & $\ldots$ \\
\hline
\end{tabular}

v Estimated $\log \log _{10}$ of ' $\mathrm{Ca}$. L. asiaticus' cells per gram of new shoots required for bacterium acquisition by 10 or $20 \%$ of $D$. citri adults after a 48 -h acquisition access period. Titer estimated based on a standard curve, as described (Lopes et al. 2013). Quantification cycle values above 34.0 were considered negative for new shoot or $D$. citri samples.

${ }^{w} P<0.001$ for all comparisons.

x Percentage of ' $\mathrm{Ca}$. L. asiaticus'-positive new shoots.

y Percentage of ' $\mathrm{Ca}$. L. asiaticus'-positive insects.

z 'Ca. L. asiaticus' titers in insects.

Table 3. Rainfall totals and the number of rain days recorded in three locations in the main citrus-growing area of Brazil in wet and dry periods from September 2012 to August 2014

\begin{tabular}{|c|c|c|c|c|c|c|c|c|}
\hline \multirow[b]{3}{*}{ Location $^{\mathrm{z}}$} & \multicolumn{4}{|c|}{ September to April } & \multicolumn{4}{|c|}{ May to August } \\
\hline & \multirow[b]{2}{*}{ 2012-13 } & \multirow[b]{2}{*}{ 2013-14 } & \multicolumn{2}{|c|}{ Averages } & \multirow[b]{2}{*}{ 2012-13 } & \multirow[b]{2}{*}{ 2013-14 } & \multicolumn{2}{|c|}{ Averages } \\
\hline & & & 2012-2014 & 2006-2015 & & & 2012-2014 & 2006-2015 \\
\hline \multicolumn{9}{|l|}{ Rainfall (mm) } \\
\hline Analândia & 1,509 & 1,327 & $1,418.0$ & $1,539.1 \pm 69.2$ & 265 & 108 & 186.5 & $175.9 \pm 31.0$ \\
\hline Frutal & 1,320 & 1,136 & $1,228.0$ & $1,566.4 \pm 96.0$ & 182 & 60 & 121.0 & $92.5 \pm 16.0$ \\
\hline $\mathrm{CG}$ & 1,324 & 1,377 & $1,350.5$ & $1,624.0 \pm 79.9$ & 166 & 78 & 122.0 & $85.3 \pm 12.8$ \\
\hline \multicolumn{9}{|l|}{ Rain days $(n)$} \\
\hline Analândia & 82 & 79 & 80.5 & $91.6 \pm 4.1$ & 18 & 8 & 13.0 & $13.3 \pm 1.6$ \\
\hline Frutal & 94 & 82 & 88.0 & $98.5 \pm 3.5$ & 10 & 6 & 8.0 & $8.5 \pm 0.8$ \\
\hline $\mathrm{CG}$ & 86 & 79 & 82.5 & $98.6 \pm 3.9$ & 9 & 6 & 7.5 & $7.1 \pm 0.7$ \\
\hline
\end{tabular}

${ }^{\mathrm{z}} \mathrm{CG}=$ Comendador Gomes.

Table 4. Multiple linear regression models for predicting 'Candidatus Liberibacter asiaticus' titer in new flushes of symptomatic branches of huanglongbingaffected citrus trees based on weather data registered from September 2012 to September 2014 in Analândia, Frutal, and Comendador Gomes orchards, during three time intervals prior the date of new shoot sampling (Days)

\begin{tabular}{|c|c|c|c|c|c|c|c|c|c|}
\hline \multirow[b]{2}{*}{ Days } & \multicolumn{4}{|c|}{ Components of the regression model ${ }^{v}$} & \multicolumn{5}{|c|}{ Statistics } \\
\hline & Incpt $^{w}$ & $\leq 15^{\circ} \mathrm{C}^{\mathrm{x}}$ & $\geq 30^{\circ} \mathrm{C}^{\mathrm{x}}$ & Rain $(\mathbf{m m})^{y}$ & $F$ & $R^{2}$ & $\operatorname{Adj} R^{2 z}$ & $P$ value & Model $P$ \\
\hline 7 & 2.219 & 0.410 & -0.36 & 0.405 & 5.67 & 0.55 & 0.45 & 0.009324 & 0.0175 \\
\hline 15 & 1.943 & 0.528 & -0.38 & 0.642 & 19.07 & 0.80 & 0.76 & 0.000032 & 0.0095 \\
\hline 30 & 1.210 & 0.690 & -0.32 & 0.690 & 14.60 & 0.76 & 0.71 & 0.000136 & 0.1102 \\
\hline
\end{tabular}

$\mathrm{v}$ Significant $\beta$ coefficients are in bold.

w Intercept.

${ }^{x}$ Number of hours at $\leq 15^{\circ} \mathrm{C}$ or $\geq 30^{\circ} \mathrm{C}$.

y Cumulative rainfall.

${ }^{\mathrm{z}}$ Adjusted $R^{2}$. 
proximity, the farm is about $550 \mathrm{~m}$ distant from the river edge and about $30 \mathrm{~m}$ higher than the water level. Therefore, the Rio Grande probably significantly influences the climate where the farm is located, favoring the prevalence of temperatures below $15^{\circ} \mathrm{C}$ (as recorded in this study) and also affecting the level of soil moisture which, in combination with low temperatures, resulted in ' $\mathrm{Ca}$. L. asiaticus' titers statistically similar to those registered in Analândia, located $250 \mathrm{~km}$ south.

In growth chambers, the impact of high temperatures on ' $\mathrm{Ca}$. L. asiaticus' titers appeared after as few as 4 days of plant exposure (Lopes et al. 2013), a trend that was also observed in the field. Even though the association was stronger with the data collected during the 15- and 30-day periods prior to the sampling date, significant correlation occurred with the data collected after as early as a 7-day interval.

Contrary to the results in this study, no significant correlations were previously observed between bacterium titer and acquisition rates by $D$. citri (Lopes et al. 2013), which was attributed to a potential effect of the temperature on ' $\mathrm{Ca}$. L. asiaticus' survival within the new shoots, affecting the proportion of live and dead ' $\mathrm{Ca}$. L. asiaticus' cells in plant tissues. The results here presented and the results from another study (Coletta-Filho et al. 2014) suggest, however, that it could have been related to change in insect sampling procedures. In previous studies (Lopes et al. 2013), 'Ca. L. asiaticus' titers were estimated in pooled samples of five insects, not allowing for more precise analysis afforded by sampling individual ACP.

In this study, 'Ca. L. asiaticus' titer in new shoots also correlated positively with the percentage of insects carrying the bacterium and with the titer of the bacterium in individual insects, with the dose of ' $C a$. L. asiaticus' in new shoots for effective ' $C a$. L. asiaticus' acquisition (ED) varying between locations. The ED for 10 and $20 \%$ of the insects were higher for those that fed on new shoots from Comendador Gomes and Frutal than those from Analândia. This suggests that, for the same acquisition rate, more bacterium cells are needed in new shoots from trees from a warmer and drier condition than from those from a relatively wetter and cooler environment. However, this result should be taken cautiously. ' $C a$. L. asiaticus' quantification in new shoots was based strictly on qPCR, which amplifies DNA from live and dead cells if present. Therefore, the same titer value converted from qPCR data could represent different amounts of live cells, as observed in symptomatic mature leaves (Trivedi et al. 2009), reinforcing the suspicion for HLB behavior and ' $\mathrm{Ca}$. L. asiaticus' dissemination recorded in Pakistan (Razi et al. 2014).

In attempts to identify the best time for leaf sampling, genetic variation in ' $\mathrm{Ca}$. L. asiaticus' populations, and the potential effect of nutritional treatments or environmental changes on bacterium multiplication, ' $C a$. L. asiaticus' behavior over time in mature leaves of field-growing trees has been the subject of other investigators (Gottwald et al. 2012; Sauer et al. 2015). ' $C a$. L. asiaticus' titers were higher during periods of milder climate. The results here presented corroborate those from previous studies and, in addition, would be more meaningful for the understanding of HLB spread because they involved assessments of ' $\mathrm{Ca}$. L. asiaticus' in new shoots, the preferred citrus tissues for ACP feeding (Yang et al. 2013).

This study also involved assessments of ' $\mathrm{Ca}$. L. asiaticus' titer in the body of the insects. The lower the titer in new shoots, the lower the titer within the insects. Whether ' $\mathrm{Ca}$. L. asiaticus' titer in the insects would affect the time needed for them to become able to transmit to a healthy tree (latent period) is not known.

In this study ' $C a$. L. asiaticus' acquisition was assessed using adult psyllids, which were allowed to feed for a 48-h period on detached new shoots under lab conditions. With this method, any potential

Table 5. Weather data recorded inside the cages during the last 15 days immediately before each date of sampling of new shoots from symptomatic branches of 'Candidatus Liberibacter asiaticus'-infected sweet orange trees growing in three locations within the major citrus area of Brazil from September 2012 to September $2014^{\mathrm{z}}$

\begin{tabular}{|c|c|c|c|c|c|c|c|c|c|}
\hline \multirow[b]{2}{*}{ Sampling date } & \multicolumn{3}{|c|}{ Number of hours $<15^{\circ} \mathrm{C}$} & \multicolumn{3}{|c|}{ Number of hours $>30^{\circ} \mathrm{C}$} & \multicolumn{3}{|c|}{ Rainfall totals (mm) } \\
\hline & Ana & Fru & CG & Ana & Fru & CG & Ana & Fru & CG \\
\hline September, October 2012 & 140 & 100 & 0 & 110 & 120 & 126 & 8 & 0 & 0 \\
\hline March 2013 & 0 & 0 & 0 & 90 & 113 & 140 & 145 & 130 & 47 \\
\hline June, July 2013 & 137 & 26 & 0 & 43 & 51 & 65 & 6 & 27 & 15 \\
\hline November 2013 & 29 & 0 & 0 & 81 & 88 & 86 & 183 & 92 & 108 \\
\hline February 2014 & 4 & 0 & 0 & 169 & 162 & 159 & 23 & 5 & 43 \\
\hline August, September 2014 & 86 & 53 & 4 & 106 & 97 & 122 & 2 & 0 & 0 \\
\hline Total & 396 & 179 & 4 & 599 & 631 & 698 & 367 & 254 & 213 \\
\hline
\end{tabular}

${ }^{\mathrm{z}}$ Locations: Ana $=$ Analândia, Fru $=$ Frutal, and CG $=$ Comendador Gomes.

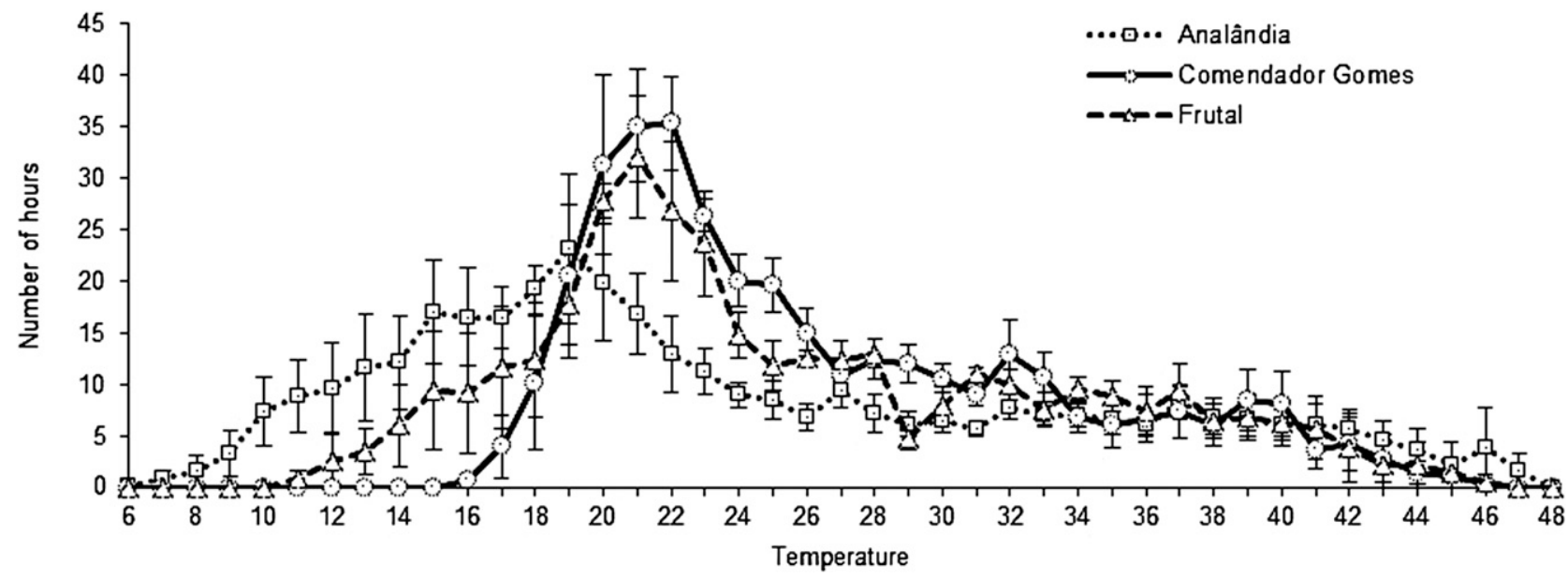

Fig. 2. Averages of the total number of hours at each degree Celsius recorded inside the cages in Analândia, Comendador Gomes, or Frutal from September 2012 to September 2014 during the 15-day period prior to new shoot samplings. Bars represent the standard error of the average number of hours for the six evaluation dates carried out in each location. 
influence of the environmental conditions that predominated in the distinct locations and sampling dates on feeding behavior of the insects and, consequently, on their ability to acquire the pathogen was isolated. Inside the tubes, the new shoots usually do not survive longer than 4 days (results not shown), impeding the use of nymphs for ' $\mathrm{Ca}$. L. asiaticus' acquisition, especially if the objective is to allow the insects to complete their life cycles on the new shoots, a situation that might occur in the field, particularly in areas of deficient psyllid control. Therefore, new experiments have been carried out in which ' $C a$. L. asiaticus' acquisition by adults and nymphs was compared using symptomatic potted plants instead of detached shoots. Although nymphs were, in general, more efficient than adults, confirming previous studies (Pelz-Stelinski et al. 2010), adults and nymphs acquired the bacterium at lower rates when the titer of ' $\mathrm{Ca}$. L. asiaticus' in the new shoots was lower than an average log 2.5 cells/g of tissue, a situation very common in Comendador Gomes, as indicated in this study (Fig. 1).

In this work, we provided additional evidence of a negative impact of a warmer and drier environment on even the heat-tolerant ' $\mathrm{Ca}$. $\mathrm{L}$. asiaticus' species which, in the field, may be reducing its ability to move from tree to tree within and between orchards. Although to a much lower extent, the climate impact on ' $\mathrm{Ca}$. L. asiaticus' seems analogous to the high temperatures on ' $\mathrm{Ca}$. L. africanus' in Africa (Schwarz and Green 1972), which makes the associated greening disease in that country apparently easier to manage than the disease affected by ' $\mathrm{Ca}$. L. asiaticus' in other countries. The impact on ' $\mathrm{Ca}$. L. asiaticus' also seems analogous to that of high temperatures on ' $\mathrm{Ca}$. $\mathrm{L}$. americanus' and to the inherent lower ability of this bacterium to multiply in citrus trees (Lopes et al. 2009b). Both heat sensitivity and lower titer in citrus, combined with diseased tree removal, may have been the main causes for the deep decline of ' $\mathrm{Ca}$. L. americanus' in Brazil. The fate of ' $\mathrm{Ca}$. L. americanus' and the result for ' $\mathrm{Ca}$. L. asiaticus' observed in this work highlight the importance of any HLB control measures that ultimately result in lower titers of the bacterium in young citrus tissues.

\section{Acknowledgments}

We thank G. A. C. Beattie, Adjunct Professor, University of Western Sydney, and L. W. Timmer, Professor Emeritus, University of Florida, Lake Alfred, for useful suggestions during manuscript preparation. This work was partially financed by Fundação de Amparo à Pesquisa do Estado de São Paulo, grant number 2014/ 12534-2.

\section{Literature Cited}

Ammar, E.-D., Walter, A. J., and Hall, D. G. 2013. New excised-leaf assay method to test inoculativity of Asian citrus psyllid (Hemiptera: Psyllidae) with Candidatus Liberibacter asiaticus associated with citrus huanglongbing disease. J. Econ. Entomol. 106:25-35.

Aubert, B. 1990. Integrated activities for the control of huanglongbing-greening and its vector Diaphorina citri Kuwayama in Asia. Pages 133-144 in: Proc. 4th Int. Asia Pac. Conf. Citrus Rehabilitation, Chiang Mai, Thailand. B. Aubert, S. Tontyaporn, and D. Buangsuwon, eds. FAO UNDP, Rome.

Beattie, G. A. C., and Barkley, P. B. 2009. Huanglongbing and Its Vectors. A Pest Specific Contingency Plan for the Citrus and Nursery and Garden Industries, 2nd ed. Horticultural Australia Ltd., Sydney, NSW, Australia. Online publication. http://researchdirect.westernsydney.edu.au/islandora/object/uws: 31219

Belasque Júnior, J., Filho, A. B., Bassanezi, R. B., Barbosa, J. C., Fernandes, G., Yamamoto, P. T., Lopes, S. A., Machado, M. A., Junior, P. L., Ayres, A. J., and Massari, C. A. 2009. Base científica para a erradicação de plantas sintomáticas e assintomáticas de Huanglongbing (HLB, Greening) visando o controle efetivo da doença. Trop. Plant Pathol. 34:137-145.

Bové, J. M. 2006. Huanglongbing: A destructive, newly-emerging, century-old disease of citrus. J. Plant Pathol. 88:7-37.

Bové, J. M., Calavan, E. C., Capoor, S. P., Cortez, R. E., and Schwarz, R. E. 1974. Influence of temperature on symptoms of California stubborn, South Africa greening, India citrus decline, and Philippines leaf mottling diseases. Page 12 in Proc. 6th Conf. Int. Org. Citrus Virol. International Organization of Citrus Virologists, Riverside, CA.

Capoor, S. P., Rao, D. G., and Viswanath, S. M. 1967. Diaphorina citri Kuwayama, a vector of the greening disease of citrus in India. Indian J. Agric. Sci. 37:572-576.

Cifuentes-Arenas, J. C., Oliveira, H. T., Góes, A., Miranda, M. P., and Lopes, S. A. 2016. Monitoring citrus flush shoot ontogeny as a potential strategy for HLB and psyllid management. Page 20 in: 20th Conf. Int. Org. Citrus Virol.
Chongqing, China. M. Melzer, ed. International Organization of Citrus Virologists, Riverside, CA.

Coletta-Filho, H. D., Daugherty, M. P., Ferreira, C., and Lopes, J. R. S. 2014 Temporal progression of 'Candidatus Liberibacter asiaticus' infection in citrus and acquisition efficiency by Diaphorina citri. Phytopathology 104: 416-421.

Coletta-Filho, H. D., Targon, M. L. P. N., Takita, M. A., De Negri, J. D., Pompeu, J., Machado, M. A., do Amaral, A. M., and Muller, G. W. 2004. First report of the causal agent of huanglongbing ("Candidatus Liberibacter asiaticus") in Brazil. Plant Dis. 88:1382.

da Costa-Lima, Â. M. 1942. Homópteros. Insetos Bras. 3:327. Online publication. http://www.acervodigital.ufrrj.br/insetos/insetos.htm

Fundecitrus. 2015a. Citrus tree inventory and orange production forecast for the 2015-2016 season of the São Paulo and west-southwest of Minas Gerais citrus belt. Araraquara, SP, Brazil. Online publication. http://www. fundecitrus.com.br/pdf/pes_relatorios/Citrus_Tree_Inventory_and_Orange_ Production_Forecast_Expanded_Version_July_01.pdf

Fundecitrus. 2015b. Levantamento mostra que manejo aplicado para a CVC fez efeito, mas que parte dos citricultores estão deixando de erradicar o HLB. Citricultor 7:8-11.

Gasparoto, M. C. G., Coletta-Filho, H. D., Bassanezi, R. B., Lopes, S. A., Lourenço, S. A., and Amorim, L. 2012. Influence of temperature on infection and establishment of "Candidatus Liberibacter americanus" and "Candidatus Liberibacter asiaticus" in citrus plants. Plant Pathol. 61:658-664.

Gómez-Torres, M. L. 2009. Estudos bioecológicos de Tamarixia radiata (Waterston, 1922) (Hymenoptera: Eulophidae) para o controle de Diaphorina citri Kuwayama, 1907 (Hemiptera: Psyllidae). Online publication. http://www. teses.usp.br/teses/disponiveis/11/11146/tde-15042009-073937/es.php

Gottwald, T. R., Graham, J. H., Irey, M. S., McCollum, T. G., and Wood, B. W. 2012. Inconsequential effect of nutritional treatments on huanglongbing control, fruit quality, bacterial titer and disease progress. Crop Prot. 36:73-82.

Khan, S. Z., Arif, M. J., Hoddle, C. D., and Hoddle, M. S. 2014. Phenology of Asian citrus psyllid (Hemiptera: Liviidae) and associated parasitoids on two species of Citrus, Kinnow mandarin and sweet orange, in Punjab Pakistan. Environ. Entomol. 43:1145-1156.

Li, W., Levy, L., and Hartung, J. S. 2009. Quantitative distribution of 'Candidatus Liberibacter asiaticus' in citrus plants with citrus huanglongbing. Phytopathology 99:139-144.

Liu, Y. H., and Tsai, J. H. 2000. Effects of temperature on biology and life table parameters of the Asian citrus psyllid, Diaphorina citri Kuwayama (Homoptera: Psyllidae). Ann. Appl. Biol. 137:201-206.

Lopes, S., Luiz, F., Oliveira, H., Mendonça, W., Furtado, E., Scaloppi, J., Scaloppi, E., and Barbosa, J. 2015. Seasonal variation in "Candidatus Liberibacter asiaticus" titers in new flushes from citrus trees growing in locations with distinct climates. J. Citrus Pathol. 2:26-27.

Lopes, S. A., Bertolini, E., Frare, G. F., Martins, E. C., Wulff, N. A., Teixeira, D. C., Fernandes, N. G., and Cambra, M. 2009a. Graft transmission efficiencies and multiplication of "Candidatus Liberibacter americanus" and "Ca. Liberibacter asiaticus" in citrus plants. Phytopathology 99:301-306.

Lopes, S. A., Frare, G. F., Bertolini, E., Cambra, M., Fernandes, N. G., Ayres, A. J., Marin, D. R., and Bové, J. M. 2009b. Liberibacters associated with citrus huanglongbing in Brazil: 'Candidatus Liberibacter asiaticus' is heat tolerant, 'Ca. L. americanus' is heat sensitive. Plant Dis. 93:257-262.

Lopes, S. A., and Luiz, F. Q. B. F. 2013. Candidatus Liberibacter asiaticus multiplication in Diaphorina citri is affected by temperature. Page 77 in: Proc. 19th Conf. Int. Org. Citrus Virol. Mpumalanga, South Africa. International Organization of Citrus Virologists, Riverside, CA.

Lopes, S. A., Luiz, F. Q. B. F., Martins, E. C., Fassini, C. G., Sousa, M. C., Barbosa, J. C., and Beattie, G. A. C. 2013. 'Candidatus Liberibacter asiaticus' titers in citrus and acquisition rates by Diaphorina citri are decreased by higher temperature. Plant Dis. 97:1563-1570.

Manjunath, K. L., Halbert, S. E., Ramadugu, C., Webb, S., and Lee, R. F. 2008 Detection of 'Candidatus Liberibacter asiaticus' in Diaphorina citri and its importance in the management of citrus huanglongbing in Florida. Phytopathology 98:387-396.

McFarland, C. D., and Hoy, M. A. 2001. Survival of Diaphorina citri (Homoptera: Psyllidae), and its two parasitoids, Tamarixia radiata (Hymenoptera: Eulophidae) and Diaphorencyrtus aligarhensis (Hymenoptera: Encyrtidae), under different relative humidities and temperature regimes. Fla. Entomol. 84:227-233.

Nava, D. E., Torres, M. L. G., Rodrigues, M. D. L., Bento, J. M. S., and Parra, J. R. P. 2007. Biology of Diaphorina citri (Hem., Psyllidae) on different hosts and at different temperatures. J. Appl. Entomol. 131:709-715.

Nunes, W. M. de C., De Souza, E. B., Junior, R. P. L., Salvador, C. A., Rinaldi, D. A., Filho, J. C., and Paiva, P. G. 2010. Plano de ação para o controle de huanglongbing no estado do Paraná, Brasil. Citrus Res. Technol. 31: 169-177.

Pelz-Stelinski, K. S., Brlansky, R. H., Ebert, T. A., and Rogers, M. E. 2010. Transmission parameters for Candidatus Liberibacter asiaticus by Asian citrus psyllid (Hemiptera: Psyllidae). J. Econ. Entomol. 103:1531-1541.

Razi, M. F., Keremane, M. L., Ramadugu, C., Roose, M., Khan, I. A., and Lee, R. F. 2014. Detection of citrus huanglongbing-associated 'Candidatus Liberibacter asiaticus' in citrus and Diaphorina citri in Pakistan, seasonal 
variability, and implications for disease management. Phytopathology 104: 257-268.

Rolim, G. de S., de Camargo, M. B. P., Lania, D. G., and de Moraes, J. F. L. 2007. Classificação climática de Köppen e de Thornthwaite e sua aplicabilidade na determinação de zonas agroclimáticas para o estado de São Paulo. Bragantia 66:711-720.

Sauer, A. V., Zanutto, C. A., Nocchi, P. T. R., Machado, M. A., Bock, C. H., and Nunes, W. M. C. 2015. Seasonal variation in populations of 'Candidatus Liberibacter asiaticus' in citrus trees in Paraná State, Brazil. Plant Dis. 99:1125-1132.

Schwarz, R. E., and Green, G. C. 1972. Heat requirements for symptom suppression and inactivation of the greening pathogen. Pages 44-51 in: Proc. 5th Conf. Int. Org. Citrus Virol. Tokyo. W. C. Price, ed. International Organization of Citrus Virologists, Gainesville, FL.

Teixeira, D. C., Ayres, J., Kitajima, E. W., Danet, L., Jagoueix-Eveillard, S., Saillard, C., and Bové, J. M. 2005. First report of a huanglongbing-like disease of Citrus in Sao Paulo State, Brazil and association of a new Liberibacter species, "Candidatus Liberibacter americanus", with the disease. Plant Dis. 89:107.

Teixeira, D. C., Wulff, N. A., Martins, E. C., Kitajima, E. W., Bassanezi, R., Ayres, A. J., Eveillard, S., Saillard, C., and Bové, J. M. 2008. A phytoplasma closely related to the Pigeon Pea Witches'-Broom phytoplasma (16Sr IX) is associated with citrus huanglongbing symptoms in the State of São Paulo, Brazil. Phytopathology 98:977-984.

Thao, M. L., Moran, N. A., Abbot, P., Brennan, E. B., Burckhardt, D. H., and Baumann, P. 2000. Cospeciation of psyllids and their primary prokaryotic endosymbionts. Appl. Environ. Microbiol. 66:2898-2905.

Trivedi, P., Sagaram, U. S., Kim, J.-S., Brlansky, R. H., Rogers, M. E., Stelinski, L. L., Oswald, C., and Wang, N. 2009. Quantification of viable Candidatus Liberibacter asiaticus in hosts using quantitative PCR with the aid of ethidium monoazide (EMA). Eur. J. Plant Pathol. 124:553-563.

Yamamoto, P. T., Felippe, M. R., Garbim, L. F., Coelho, J. H. C., Martins, E. C., Leite, A. P. R., Sousa, M. C., Abrahão, D. P. B., and Braz, J. D. 2006. Diaphorina citri (Kuwayama) (Hemiptera: Psyllydae): Vector of the bacterium Candidatus Liberibacter americanus. Page 26 in: Proc. Huanglongbing-Greening Int. Workshop, Ribeirão Preto, SP, Brazil.

Yang, Y., Beattie, G. A. C., Spooner-Hart, R. N., Huang, M., Barchia, I., and Holford, P. 2013. Influences of leaf age and type, non-host volatiles, and mineral oil deposits on the incidence, distribution, and form of stylet tracks of Diaphorina citri. Entomol. Exp. Appl. 147:33-49. 